\title{
INVESTIGADORES BRASILEIROS EM PORTUGAL: PENSANDO A EDUCAÇÃO PARA O FUTURO.
}

\section{Apresentação}

Integra o presente número especial um conjunto de artigos assinados por pesquisadores vinculados ao QualisBrasil (IQB). Os textos apresentados refletem o trabalho de investigadores brasileiros que têm estreita relação com Universidades portuguesas e concordam com Paulo Freire (2000, p. 67): "Se a educação sozinha não transforma a sociedade, sem ela, tampouco, a sociedade muda". Como cidadãos e pesquisadores, acreditam que a intervenção no mundo e, sobretudo na realidade atual brasileira, deve ser direcionada de forma contextualizada e ética visando a articulação dos aspectos educacionais, político, sociais e culturais.

Tendo em vista os diversos e atuais desafios no âmbito da educação, somamos esforços no sentido de compreender e, sobretudo, pensar a educação para o futuro, conscientes da complexidade crescente dos processos sociais, econômicos e políticos do mundo em que vivemos e que se encontra em constante processo de mudança. O que nos permite acreditar que a educação não pode restringir-se simplesmente aos problemas de sala de aula. Ela precisa ir além se quiser contribuir com a sociedade. Ao contrário, a educação continua se organizando de modo ineficaz, sem oferecer respostas aos desafios que demandam da contemporaneidade e sem contribuir com a sociedade.

O número especial que se materializa pela Revista Ibero-Americana de Estudos em Educação conta com a participação de investigadores com renomada experiência nacional e internacional nas suas áreas de atuação, vinculados a Instituições Universitárias do Brasil e de Portugal.

A obra é composta por áreas temáticas, que se caracterizam como dilemas atuais, a saber: Processos Formativos, Políticas Públicas Educacionais, Temas Atuais em Educação e Cultura e Contributos da Psicologia da Educação e da Psicopedagogia.

Relativamente aos Processos Formativos, são apresentados três artigos. O primeiro intitula-se Percursos formativos e experiências integradoras no Ensino 
Superior: partilhas no Brasil e em Portugal e aborda os processos formativos para a docência no Ensino Superior nos contextos brasileiro e português. A partir do olhar para duas pesquisas realizadas, as autoras retratam as ações desenvolvidas na implantação de ações institucionais voltadas à docência no Ensino Superior. Na sequência, $\boldsymbol{O}$ processo de formação de professores da Educação Básica no interior de uma Escola de Ensino Fundamental: o olhar dos graduandos sobre o ser professor e a prática profissional busca compreender o significado de um Projeto de Formação de Professores, buscando dialogar entre os relatos dos entrevistados e os estudos teóricos do campo da formação de professores. Em seguida, Formação profissional e cristã da juventude salesiana e a pedagogia de Dom Bosco analisa, por meio do uso da pedagogia de Dom Bosco portuguesa e brasileira, como os diferentes atores sociais, vivenciando realidades específicas, apropriam-se do saber educacional dos salesianos para produzir suas histórias educacionais constatando abrangências e limitações comuns em seus diferenciados contextos.

No âmbito das Políticas Públicas Educacionais, são apresentados quatro manuscritos. O primeiro, denominado Indagações sobre as políticas educacionais e reflexões sobre demandas percebidas pelo Estado brasileiro: tópicos para análise circunstanciada de seus instrumentos de ação indica, pela análise cognitiva de políticas públicas, alguns dos principais pontos de discussão nos instrumentos utilizados por essas políticas para a área da educação no Brasil atual. Posteriormente, Educação social e políticas públicas de juventude: experiências socioeducativas no Brasil e em Portugal investiga as percepções de jovens sobre a educação social. Com base na sociologia da juventude, a escrita afirma-se como um estudo de caso, de natureza qualitativa, realizado consoante o procedimento metodológico intitulado retratos sociológicos. Em seguida, Revista Nova Escola e avaliação externa: como ocorre a circulação de ideias realiza um levantamento e a análise das publicações regulares e especiais da revista Nova Escola que abordaram o assunto Avaliação Externa das Aprendizagens entre os anos de 2006 e 2015. Por fim, é apresentado estudo direcionado às políticas e práticas de inclusão e valorização da igualdade no Instituto Federal de Educação, Ciência e Tecnologia de Mato Grosso - IFMT, intitulado Agir a favor da inclusão: IFMT em ação.

Na sequência, são abordados temas em Educação e Cultura através de quatro artigos. O primeiro - denominado $\boldsymbol{O}$ cyberbullying em contexto universitário do Brasil e Portugal: vitimização, emoções associadas e estratégias de enfrentamento - 
descreve como os estudantes universitários do Brasil e de Portugal experienciaram situações de cyberbullying no papel de vítimas, considerando-se algumas variáveis sociodemográficas. $\mathrm{O}$ artigo também analisa diferenças em função do contexto relativamente aos comportamentos de vitimização, as emoções e as estratégias utilizadas pelas vítimas. A relação entre a concepção de administrador e a percepção sobre Ensino Superior de Administração: a ouvir os protagonistas do Ensino Superior de Administração busca apresentar a relação entre a concepção idealizada de Administrador e a percepção dos protagonistas a respeito do ensino superior de administração. Investigações que exploram este tema são importantes devido ao potencial esvaziamento de reflexão no ensino superior no curso brasileiro de administração. Finalizamos esta área temática com o artigo A cultura participativa e as práticas de letramentos de fãs de ficção: uma investigação empírica. Trata-se de estudo exploratório com elementos da etnografia virtual sobre a cultura participativa e às práticas de letramentos digitais de fãs de ficção, cujo objetivo vislumbrou identificar como a cultura participativa se estabelece nas práticas de letramentos digitais dos fãs de ficção nos espaços virtuais.

Por fim, são apresentados os artigos da área temática Contributos da Psicologia da Educação e da Psicopedagogia. Em Motivação e estratégias de aprendizagem segundo a Teoria das Abordagens à Aprendizagem: implicações para a prática de ensino-aprendizagem, algumas contribuições sobre questões motivacionais e sobre estratégias de aprendizagem são apresentadas, uma vez que ambas possuem relação com o rendimento escolar e a qualidade na aprendizagem. Na sequência, As contribuições da ACP ao saber psicopedagógico apresenta a perspectiva de que o sujeito aprendente possui potencialidades para aprender e é por meio de comunicação empática que o psicopedagogo age como facilitador para o aprendizado e a mudança do aluno. Por fim, o estudo exploratório Psicólogos(as) escolares, diversidade sexual e escola: um estudo Brasil/Portugal apresenta caracterização sobre a atuação de psicólogas(os) escolares frente às questões relativas à diversidade sexual no contexto escolar.

Consideramos os tópicos abordados relevantes e, através de seus temas transversais em realidades diversas, buscamos dialogar através deles com questões práticas e cotidianas do cenário educacional de Brasil e Portugal.

Acreditamos, portanto, que o presente dossiê proporcione - àqueles envolvidos com as questões educacionais - esteio, recursos e percursos que possibilitem a reflexão 
e a construção de práticas conscientes, alicerçadas em teorias seja da educação, psicologia e áreas afins, permitindo, assim, pensarmos numa educação para o futuro e que traga benefícios sólidos ao nosso Brasil.

Os Organizadores:

Sidclay Bezerra de Souza João Luiz Peçanha Couto Sebastião Souza Lemes 